\title{
As vozes do indianismo em Il Guarany
}

\author{
Denise de Lima Santiago Figueiredo* \\ Paula Regina Siega** \\ Paulo Roberto Alves dos Santos"**
}

\section{Resumo}

O romantismo no Brasil deve ser visto como um movimento inseparável do esforço para a criação de um país e suas instituições que, em todas as formas de expressão cultural, transformou o indígena em símbolo da nação. A partir dessa perspectiva, o presente artigo analisa a recepção criativa que Carlos Gomes deu ao romance O Guarani (1952), de José de Alencar, publicado pela primeira vez em 1857, por meio da ópera Il Guarany (1870). Para tanto, o eixo da análise, por um lado, destaca a importância da composição vocal para a recriação das características psicológicas das personagens, o que permite observar o empenho do compositor para se afastar o mínimo possível dos traços definidos pelo romancista e com isso garantir a preservação de vínculos entre a literatura e a ópera, enquanto, por outro lado, respeita as peculiaridades das respectivas linguagens.

Palavras-chave: História da literatura. Literatura brasileira. Literatura e música.

\section{Introdução}

Na segunda metade do século XX, com a chamada "estética da recepção", a figura do leitor e $o$ ato de ler passam a ser o foco de análises que deixam de interpretar a leitura como evento passivo, meramente consumidor, para ver nela uma atividade criativa. Com as contribuições de Hans Robert Jauss e Wolfgang Iser, o leitor, entendido como receptor de um texto, passa a ser encarado como sujeito produtor, capaz de acionar o potencial

\footnotetext{
* Mestra em Letras pelo Programa de Pós-Graduação em Letras: Linguagens e Representações, da Universidade Estadual de Santa Cruz (UESC). E-mail: deniselsantiago@gmail.com

** Doutora em Línguas, Culturas e Sociedades pela Universidade de Veneza. Professora visitante na Universidade Estadual de Santa Cruz (UESC). Professora colaboradora do Programa de Pós-Graduação em Letras, da Universidade Federal do Espírito Santo (UFES). E-mail: paula.siega@gmail.com

*** Doutor em Teoria Literária pela Pontifícia Universidade Católica do Rio Grande do Sul (PUCRS). Professor pesquisador (PNPD/CAPES) na Universidade Estadual de Santa Cruz (UESC). E-mail: pauloroberto3031@uol. com.br
}

Data de submissão: 30/07/2017 - Data de aceite: ago. 2017 http://dx.doi.org/10.5335/rdes.v13i2.7275 
semântico de uma obra para, de vez em vez, atualizar o seu sentido: "é no leitor que o texto toma vida", conclui Iser (1987, p. 57). Nessa perspectiva, é por meio da fruição literária que o texto fala ao leitor, num processo de comunicação que pode engendrar as mais variadas respostas. Essas dependem não somente da "qualidade" do que se lê, mas também do universo cultural do receptor. $\mathrm{O}$ que significa que o sentido ou o valor atribuído à determinada obra está diretamente relacionado ao conjunto de experiências e referências prévias dos receptores, que Jauss (1969) denominou como "horizonte de expectativas". Embora a obra, enquanto texto, permaneça praticamente a mesma ao longo do tempo, os sentidos a ela atribuídos variam de acordo com as sucessivas gerações que sobre ela se debruçam. Entre obra e receptor instaura-se um processo dinâmico capaz de manter viva, por exemplo, a relação entre os leitores do presente e os textos do passado: "Nas artes", afirma Jauss, "o antigo deixa-se conservar somente através de sempre novas atualizações, seleções, esquecimentos e reapropriações" (1988, p. 25, tradução nossa).

Ao considerar o fenômeno da leitura e as reações que desencadeiam no leitor do texto literário, Iser (1987) desenvolve o conceito de "resposta estética", entendido como resultado da relação dialética que se estabelece entre leitor e texto. Em sintonia com o pensamento de Jauss, trata-se de levar em consideração que a obra age sobre o receptor, acionando a sua imaginação, mas o leitor também atua sobre a obra, que se transforma em objeto da sua reação. A resposta estética do leitor é motivada pela obra, que coloca em jogo a imaginação de quem lê. Como exemplo do processo imagístico acionado na mente do leitor, Iser (1987) compara as imagens livres e inacabadas geradas pela fantasia, através da leitura de um livro, e as imagens perfeitamente definidas de um filme inspirado no livro: a decepção comumente experimentada pelo leitor diante da versão cinematográfica indica a liberdade imaginativa estimulada pela leitura, que não se contenta com a definição perfeitamente objetiva dada pela outra forma de expressão. Diferentemente das imagens fotográficas,

As nossas imagens mentais não servem a deixar o personagem fisicamente visível; a sua escassez ótica é uma indicação do fato que estas iluminam o personagem não como um objeto, mas como um portador de significados (ISER, 1987 p. 211).

A transposição para o cinema de obras literárias é, provavelmente, uma das respostas criativas derivantes da leitura mais comum e está na origem da história do cinema, cujas primeiras grandes produções eram baseadas em clássicos da literatura ocidental. Nas adaptações, o roteirista transpõe para o filme as imagens suscitadas na sua imaginação, as quais ganham forma definitiva por intermédio das técnicas de filmagem e edição. $\mathrm{Na}$ transição de um meio para outro, as estratégias comunicativas do texto de partida sofrem um processo de transformação, sendo substituídas por 
outras (desde descrição do roteiro até planificação da luz, cenário, tipos de corte, edição, atores, etc.), objetivando realizar uma obra que, embora inspirada em um texto pré-existente, dele não depende para ser usufruída pelo receptor. O espectador pode ter lido o livro no qual um filme é inspirado, mas esse conhecimento prévio não é fundamental para a fruição do filme, que existe enquanto realidade estética autônoma. Leve-se em consideração que, pela sua capacidade de simplificação da linguagem literária (na Itália, as primeiras adaptações cinematográficas de textos literários eram chamadas de "reduções"), o cinema foi cogitado, no início do século $\mathrm{XX}$, como possível meio de alfabetização e elevação cultural das massas.

Antes da invenção do cinema, uma forma espetacular que se serviu da inspiração literária como princípio criativo foi a ópera. No Brasil, o maior autor desse gênero musical foi Carlos Gomes, que se firmou no imaginário cultural com a transposição musical de $O$ Guarani, acrescentando outro sentido para a designação do romance mais popular da época. A partir de então, o título passou a remeter simultaneamente a uma das principais obras da literatura brasileira do século XIX e a uma peça fundamental da história da nossa música. No que se refere à ópera, observando-se o processo de atualizações e transformações que resultou na tradução da linguagem literária à linguagem musical, é possível considerá-la como resultado da interação que se deu entre o leitor Carlos Gomes e a obra de José de Alencar. Verifica-se, aqui, aquele tipo de reação estética preconizada por Jauss, segundo a qual um receptor pode responder de diversas formas à obra, reafirmando o que já se conhece sobre ela, dando novas interpretações críticas ou, inclusive, "criando ele mesmo uma nova obra" (1988, p. 136). Assim, este trabalho investiga a recepção criativa de $O$ Guarani por Carlos Gomes, observando, especificamente, a construção vocal escolhida para os personagens do romance. Demonstra-se que o compositor, respondendo musicalmente ao romance, reagiu esteticamente ao texto literário, transpondo para o universo operístico o indianismo literário de Alencar, transformado em objeto de criação artística do compositor.

\section{Carlos Gomes e a valorização da voz}

De acordo com Niza de Castro Tank (2006), as óperas de Carlos Gomes têm o objetivo de valorizar e ressaltar a voz humana. Em suas composições, o canto sempre foi um elemento presente. Por isso, esta análise privilegia aspectos da música vocal em Il Guarany (1889), considerando-se que Gomes, como outros do período romântico, imaginou que as personagens de Alencar ganhassem vida com um tipo específico de voz, de acordo com suas posturas e seus perfis dentro da trama romanesca. A criação operística tenta seguir as características das personagens literárias, e seus traços 
psicológicos são transferidos não apenas para o texto do libreto, mas também para a composição vocal: na escolha de extensões $^{1}$, timbres ${ }^{2}$, coloratura ${ }^{3}$, dinâmicas; entre outros aspectos pertinentes ao universo da música cantada, que são neste estudo analisados.

Mammì (2001) adverte que Carlos Gomes concebeu o enredo de maneira simples, separando-o em dois blocos opostos: "os portugueses [e os espanhóis], encabeçados por D. Antônio, e os aimorés, guiados pelo cacique" (2001, p. 48). Nesse sentido, "a primeira instituição de Carlos Gomes é conferir a esses dois grupos um caráter musical semelhante" (MAMMÌ, 2001, p. 48). Embora na construção do bloco dos "portugueses" se perceba claramente uma musicalidade tonal, o modalismo se acentua no grupo dos aimorés, a melhor representação dos selvagens, por meio de composições de acordes que demonstram "propositalmente um caráter tosco" (MAMMÌ, 2001, p. 49).

Peri, o "bom selvagem" rousseauniano, vai se definindo como herói com a técnica do bel canto ${ }^{4}$ italiano, percebida pela extensão própria de um tenor, tipo de voz muito utilizada para os heróis das óperas do século XIX. Já os povos indígenas, representados pela etnia aimoré, são musicalizados por expressões estereotipadas que confirmam a ideia de "incivilidade", como demonstraremos.

Logo no primeiro ato ocorre a apresentação de todos os personagens, e no início tem-se o Coro di Cacciatori, em que todos se felicitam pela excelente caçada, bem demonstrada musicalmente, já que a orquestra também entra, embora "somente intervém nos espaços de uma estrofe para outra, com a preponderância das trompas" (1972, p. 65), escreve Salvatore Ruberti. As vozes, bem divididas em intervalos predominantemente de terça e segunda maiores, em igual número de tenores e baixos, cantando para enaltecer o feito, vão construindo afinações próprias da música ocidental. Trata-se de uma maneira eficaz de se iniciar um espetáculo, que facilita a aceitação dos ouvidos já habituados à música de tonalidades maiores ou menores.

São vozes vivas e bem ritmadas em que a melodia principal é endossada pelo Allegro deciso (Figura 1), dando a ideia de um grupo coeso. Depois entram Gonzalez e os outros espanhóis, que desmerecem as pretensões de Álvaro, o escolhido por Dom Antônio para ser marido de sua filha, Cecília. O desdém de Gonzalez fica perceptível por meio do acompanhamento orquestral que enfatiza seu caráter irônico, bem próximo do Loredano de Alencar que, no início do romance, também provoca Álvaro:

Decididamente o sarcástico italiano, com o seu espírito mordaz, achava meio de ligar a todas as perguntas do moço uma alusão que o incomodava; e isto no tom mais natural do mundo (ALENCAR, 1952, p. 15).

A orquestra utiliza os violoncelos e seu timbre mais grave para acompanhar os diálogos nos momentos de ironia, que, logo depois, se juntam às demais cordas para dar a leveza própria da hilaridade por parte dos companheiros de Gonzalez, como acentua Ruberti (1972). 
Figura 1 - Trecho de // Guarany

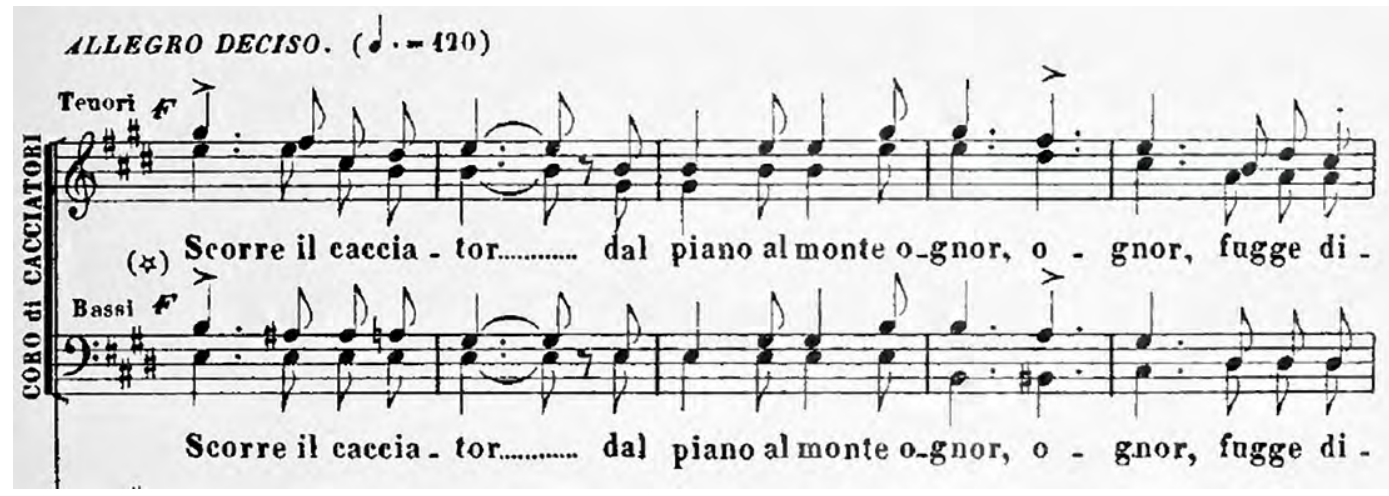

Fonte: Carlos Gomes (1889, p. 19).

O destaque a Dom Antônio de Mariz é dado pela extensão diferente em relação aos demais, que possuem vozes mais agudas. O registro grave, do baixo, composto por oitavas descendentes (Figura 2) indica, nesse sentido, a autoridade peculiar da figura do fidalgo português, como salienta Mammì (2001). Esta dinâmica vocal, com notas que vão do agudo e continuam a melodia em sua nota homônima, porém em uma região mais grave, traduz para a linguagem operística a personalidade do pai de Cecília, assim descrita por Alencar:

Homem de valor, experimentado na guerra, ativo, afeito a combater os índios, prestou grandes serviços nas descobertas e explorações do interior de Minas e Espírito Santo. Em recompensa do seu merecimento, o governador Mem de Sá lhe havia dado uma sesmaria de uma légua com fundo sobre o sertão, a qual depois de haver explorado deixou por muito tempo devoluta (1952, p. 08).

Como receptor criativo, Gomes transpõe o texto literário para a linguagem da música da seguinte maneira:

Figura 2 - Trecho de // Guarany

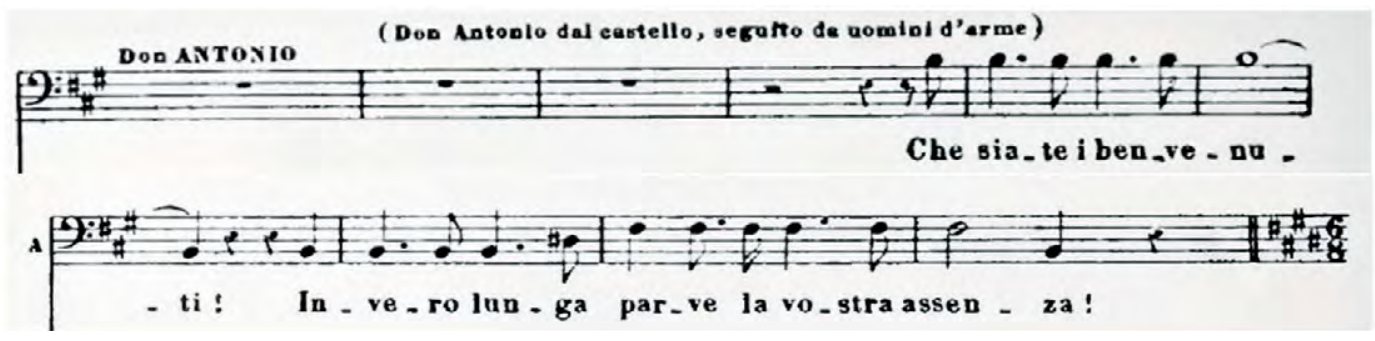

Fonte: Carlos Gomes (1889, p. 32). 
Na ópera, a participação de Dom Antônio inicia quando ele narra a dificuldade pela qual passou sua filha. Cecília, quase raptada pelos aimorés - que queriam uma jovem de seu povo, morta por um dos caçadores do fidalgo -, foi salva por um índio guarani. O português, então, apresenta Peri aos outros homens, retomando a relação amigável entre português e nativo, mantendo, porém, a supremacia do primeiro sobre o segundo, tal como na literatura:

Para mim, os índios quando nos atacam, são inimigos que devemos combater; quando nos respeitam, são vassalos de uma terra que conquistamos; mas são homens! (ALENCAR, 1952, p. 34).

O papel de Peri normalmente é destinado a um tenor dramático. Essa categoria possui timbre mais encorpado, além disso, estava em plena ascensão na ópera italiana do século XIX, sendo comumente indicada a papéis de heróis impulsivos ou enredos trágicos. O herói construído musicalmente por Carlos Gomes conserva a nobre genealogia tupi atribuída pelo romance, assim como a sua subalternidade em relação ao colonizador. A maneira de apresentá-lo na ópera é com a vitalidade criada pela orquestração, na mais pura representação do Allegro vivo colocada aos instrumentos nesta parte, como observa Ruberti:

[...] nenhuma apresentação poderia ter, musicalmente, mais intensa energia da vibrante orquestração sobre a qual se firma a ufana frase do jovem chefe guarani ao assomar à cena (1972, p. 67).

O Peri musical se apresenta confiante - como o literário que, na abertura da narrativa, aparece enfrentando uma onça - e é em sua Sortita, construída em poucos acordes vocais (Figura 3 ), que sua participação torna-se incisiva, revelando um valor que se acentua ao longo do enredo, principalmente pela força vocal de duetos e árias que virão.

Figura 3 - Trecho de // Guarany

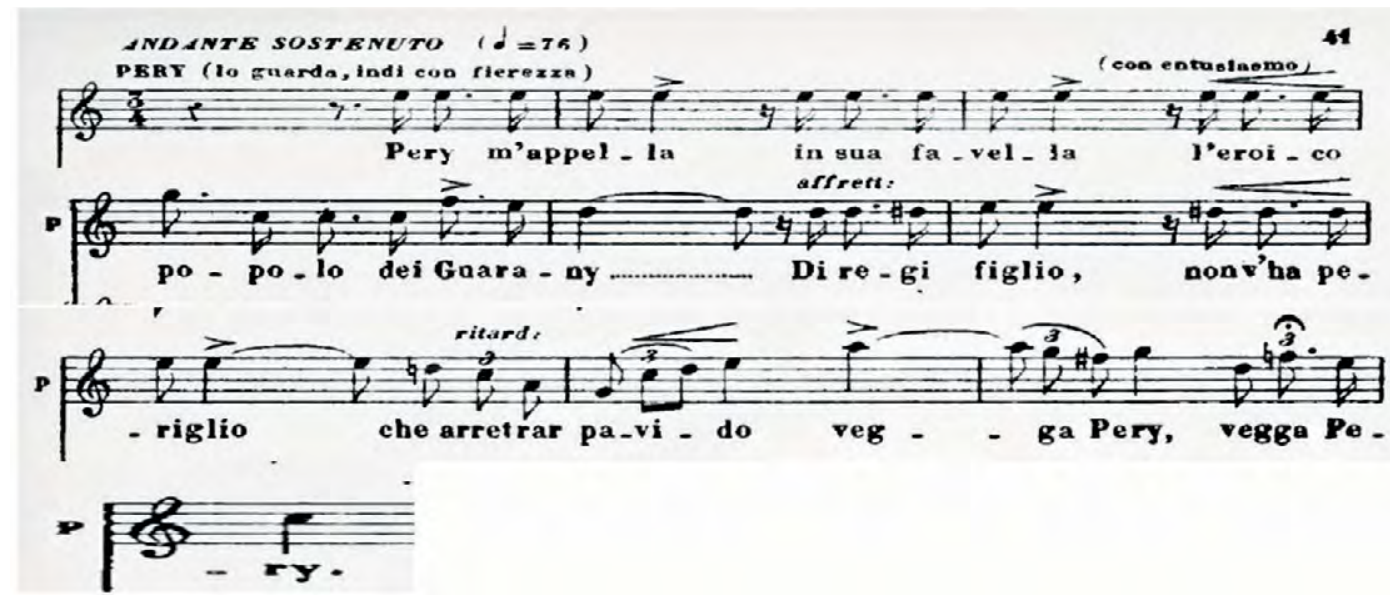

Fonte: Carlos Gomes (1889, p. 41). 
Neste mesmo ato, a apresentação de Ceci ganha contornos distintos da de Peri. Se a intenção do compositor foi construir o herói indígena gradativamente, o mesmo não aconteceu com a mocinha, uma vez que sua primeira aparição é mais ampla, ou seja, explora sua variedade vocal de maneira mais abundante, demonstrando logo no início seu papel dentro do enredo. Esse pode ser considerado um exemplo de substituição da estratégia comunicativa do texto literário por uma estratégia consonante com as especificidades do meio operístico: diversamente do que acontece na narrativa literária, que pode moldar o aspecto físico dos personagens segundo a imaginação do autor, na ópera, elas são encarnadas pelo intérprete. Para o público, porém, mais importante do que a presença corporal são as características vocais, essenciais para a percepção da personagem. Essas características, por sua vez, são bem representadas pela tessitura $^{5}$ e pelas propriedades do timbre vocal que foram dadas à Ceci operística.

$\mathrm{Na}$ definição da Ceci literária, Alencar utiliza aspectos que valorizam a beleza física, traço comum no romantismo:

Os grandes olhos azuis, meio cerrados, às vezes se abriam languidamente como para se embeberem de luz, e abaixavam de novo as pálpebras rosadas.

Os lábios vermelhos e úmidos pareciam uma flor de gardênia dos nossos campos, orvalhada pelo sereno da noite; o hálito doce e ligeiro exalava-se formando um sorriso. Sua tez, alva e pura como um floco de algodão, tingia-se nas faces de uns longes cor de rosa, que iam, desmaiando, morrer no colo em linhas suaves e delicadas (ALENCAR, 1952, p. 26).
Além da beleza que lhe é inerente, a caracterização psicológica de Ceci marca a condição de personagem pura, alegre e doce:

[...] uma moça risonha e faceira, respirando toda a graciosa gentileza, misturada de inocência e estouvamento, que dão o ar livre e a vida passada no campo (ALENCAR, 1952, p. 31).

Esses traços de sua personalidade são mantidos na obra de Carlos Gomes, que doa à protagonista a musicalidade própria ao soprano ligeiro, uma extensão vocal bem peculiar e difundida principalmente pela técnica do bel canto, muito comum no meio operístico italiano.

De acordo com Maria Elisabeth Ratzersdorf, uma das linhas melódicas construídas pela técnica do bel canto se baseia na coloratura, que se caracteriza por: "uma melodia mais ágil com diversas notas de curta duração em uma mesma sílaba, além de trinados e outros ornamentos floridos" (2002, p. 14). Assim, a maneira que Carlos Gomes encontra, no primeiro ato, para transpor ao canto a personalidade literária de Ceci é dando a agilidade de notas agudas e de curta duração. A escala em intervalos ascendentes aumenta naturalmente a pressão vocal, dando um efeito firme, porém amenizado pela leveza da personalidade de Ceci. A meninice, a alegria e a inocência, representadas por uma primeira impressão por meio da polacca: Gentile di Cuore (Figuras 4-5) - uma dança típica polonesa -, na visão de Mammì (2001, p. 49), fazem da protagonista muito mais francesa do que propriamente italiana, 
pois não se mantêm somente nas regiões agudas, uma vez que os bordados denotam "as heroínas de Meyerbeer".

Essa aproximação com Meyebeer é justificável já que "Ceci é uma moça de boa família, seu estilo é urbano e afrancesado, aqui e ali um tanto cocotte" (MAMMÌ, 2001, p. 49). Com isso, nota-se a transição entre a região mais grave para a aguda, mesclando agilidade e leveza:

Figura 4 - Trecho de // Guarany

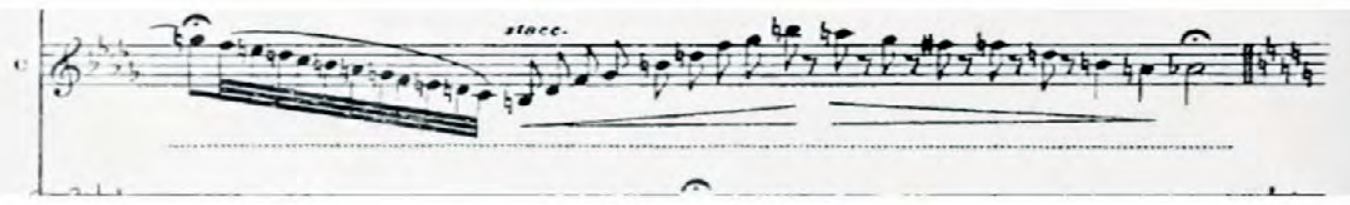

Fonte: Carlos Gomes (1889, p. 48).

Figura 5 - Trecho de // Guarany

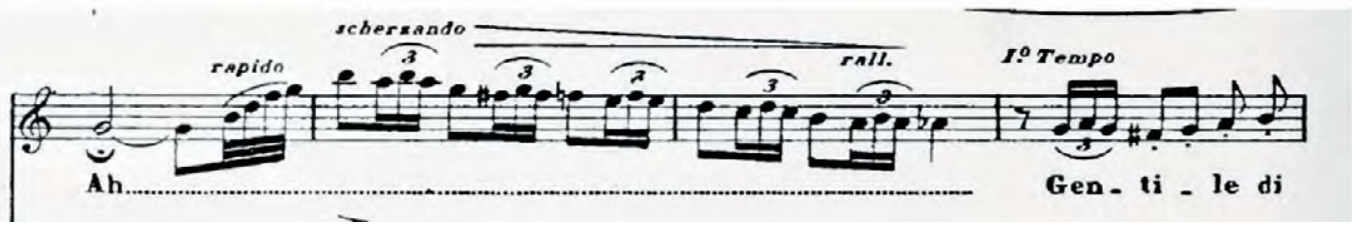

Fonte: Carlos Gomes (1889, p. 52).

Ainda no primeiro ato, Gomes ressalta o capítulo "A prece" de Alencar, trazendo com sua "Ave Maria" um momento místico à ação, como na literatura. A presença sempre dominante da voz grave de Dom Antônio (Figura 6) confirma sua autoridade solene, enquanto o clima criado pelos contrapontos de outras vozes e solistas denota obediência. Sem tirar a preponderância do fidalgo, as demais figuras trazem àquele recital uma peculiaridade ritualística: o fim de tarde, ali interpretado como instante confiado ao sagrado, como no texto de Alencar:

Um concerto de notas graves saudava o pôr do sol e confundia-se com o rumor da cascata, que parecia quebrar a aspereza de sua queda e ceder à doce influência da tarde. Era a Ave Maria (1952, p. 40).

Todo esse conjunto de impressões é visível na execução da composição gomesiana para este momento, que reafirma a supremacia do elemento religioso de herança europeia sobre os demais: 
Figura 6 - Trecho de // Guarany

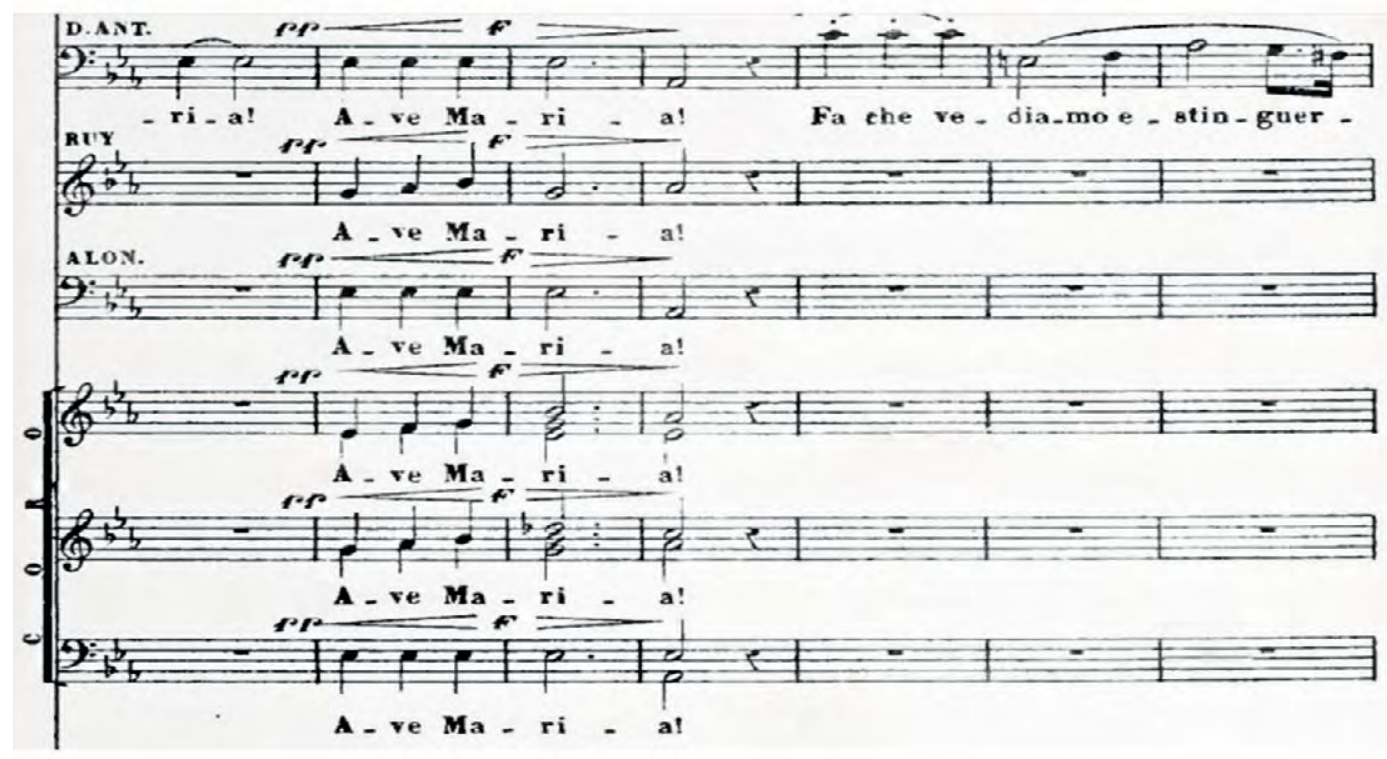

Fonte: Carlos Gomes (1889, p. 65).

O fechamento do primeiro ato traz um dos momentos mais expressivos da ópera Il Guarany: o dueto Sento una forza indomita. Segundo Mammì, este "talvez seja o melhor duo em octossílabos escritos depois de Verdi. Apesar de sua métrica 'quadrada', encadeia as diferentes seções com uma soltura que falta a muitas composições da época" (2001, p. 47). Nele, diferentemente de sua primeira participação, Peri é mais intenso e utiliza inflexões, o que consiste em uma maneira de enfatizar a voz para demonstrar determinado sentimento no caso, um artifício para valorizar a descoberta do amor por Ceci e, ainda, afirmar sua posição como herói indígena. A correspondência a esse amor é manifestada ao longo do duo, pois a construção vocal é colocada de maneira que a expressividade apareça nas melodias com aspectos distintos, dinamicamente compostos, como em um jogo de perguntas e respostas.

Então, o que era um espaço tomado por sentimentos confusos dá lugar a um consenso por meio de vozes que vão se encontrando, representando a sintonia que se estabelece entre o herói e a filha do fidalgo (Figuras 7-8). 
Figura 7 - Trecho de // Guarany

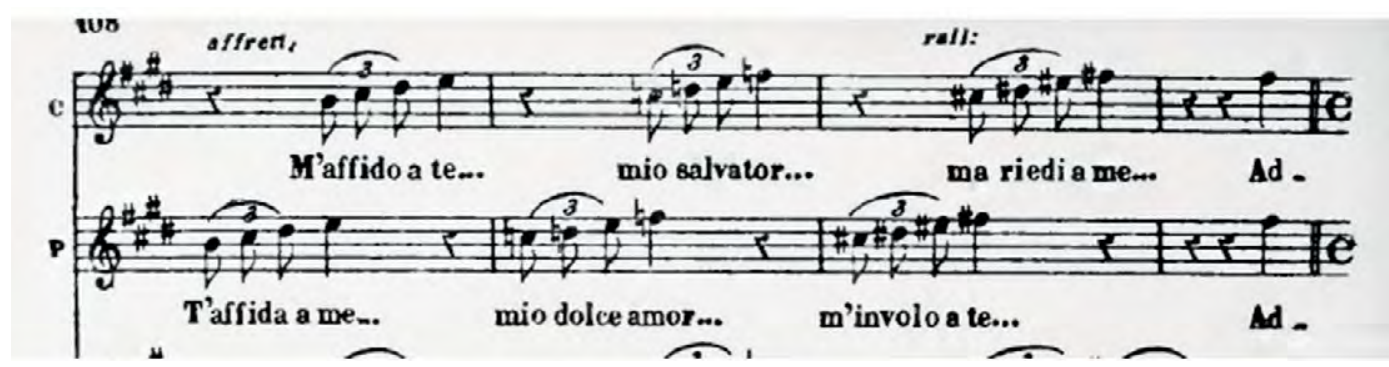

Fonte: Carlos Gomes (1889, p. 108).

Figura 8 - Trecho de // Guarany

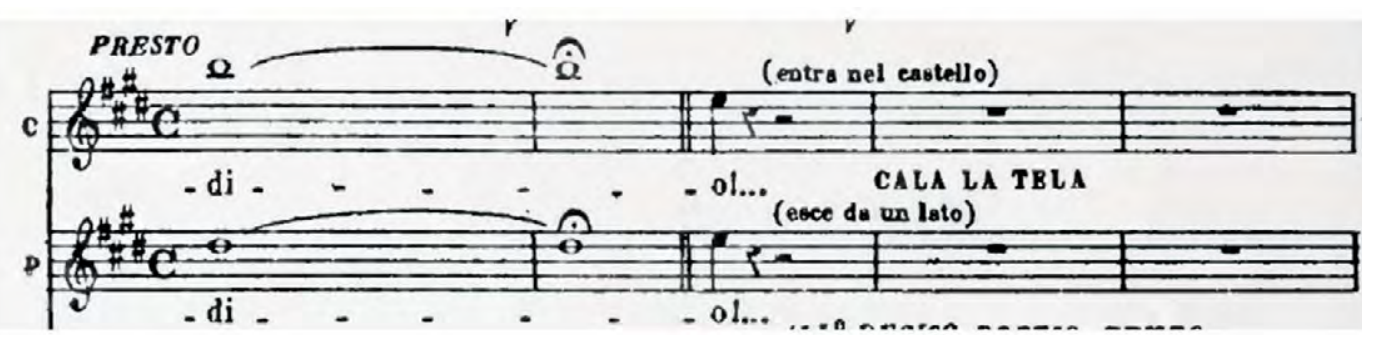

Fonte: Carlos Gomes (1889, p. 108).

O segundo ato tem início com a cena em que Peri se esconde na gruta para poder ouvir os planos de Gonzales e seus comparsas. Enquanto espera, entoa Vanto io pur superba cuna. Se na orquestração há um "desenho escuro dos violoncelos e das violas (lembra o Otello verdiano, 1887 - Dio; optei scagliarmi...)" (RUBERTI, 1972, p. 76), na parte cantada, as curvas melódicas que indicam grande variedade de notas em curto espaço de tempo também são acentuadas pelo crescendo em pontos cruciais, nos quais se concentram as notas mais agudas da melodia. Usando a notação affrettando, que indica um andamento que acelera aos poucos exatamente nestes pontos (Figura 9), Go- mes faz os compassos ganharem maior flexibilidade, mesmo com as descidas de escala, utilizando figuras com tempos mais lentos (Figura 10). Outros recursos empregados para caracterizar Peri são a mudança tonal, que leva a voz do solista a transitar em regiões diferentes por meio de notas médias e agudas, e a agilidade na melodia, diluída na mudança de padrão sonoro decorrente do emprego de figuras rítmicas inesperadas (Figura 11).

Todas essas transições na melodia cantada pelo personagem soam como singularidades que demonstram segurança, firmeza, confirmando o heroísmo do indígena em sua transposição musical da composição literária de Alencar: 
Figura 9 - Trecho de // Guarany

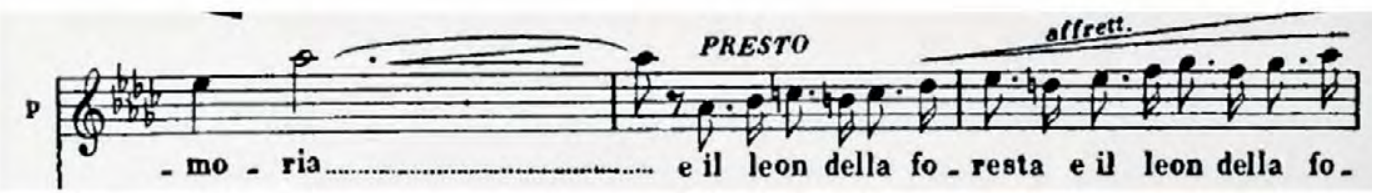

Fonte: Carlos Gomes (1889, p. 120).

Figura 10 - Trecho de // Guarany

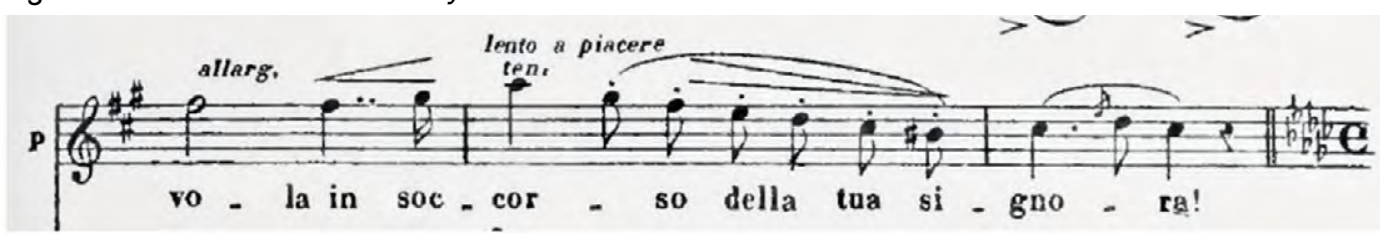

Fonte: Carlos Gomes (1889, p. 117).

Figura 11 - Trecho de // Guarany

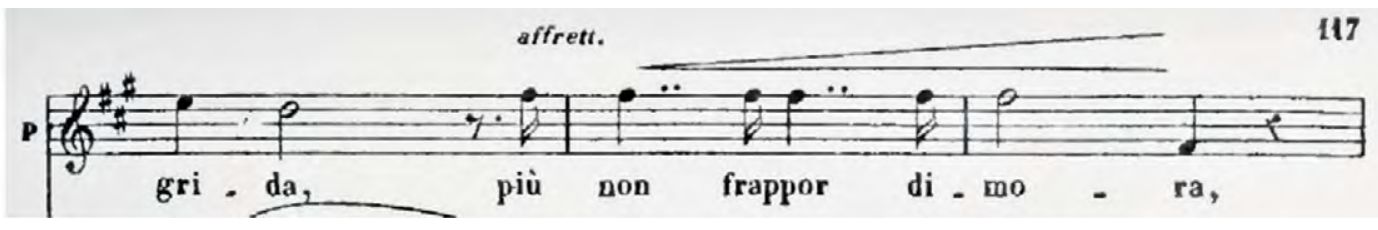

Fonte: Carlos Gomes (1889, p. 117).

Posteriormente, são apresentados os planos dos três aventureiros espanhóis que, como no romance, consistem no projeto de tomar uma mina de prata e raptar Ceci. Surpreendido por Peri, Gonzales não se intimida e confronta-o, justificando o dueto entre o tenor herói e o barítono vilão, enquanto Alonso e Rui Bento fogem. Tal como no texto de Alencar, estabelece-se o antagonismo determinado pela distância entre a bondade de Peri e a maldade de Loredano/ Gonzales, algo perceptível de maneira clara na construção musical, pois é acentuado pelo afastamento rítmico entre os personagens. Enquanto Peri usa mínimas e semínimas e uma melodia simples, porém inteira, demonstrando força, Gonzales faz uso de colcheias e semicolcheias, dando a ideia de fragmentação, quebra, fraqueza (Figura 12).

Veja-se o confronto entre a descrição literária do momento em que Peri tem Loredano em suas mãos e sua transposição musical: 
Peri mostrando nos movimentos toda a força muscular de sua organização de aço, com a mão esquerda segura à nuca de Loredano, curvava-o sob a pressão violenta, e obrigava- -o a ajoelhar. O italiano lívido, com o rosto retraído e os olhos imensamente dilatados, tinha ainda entre as mãos hirtas a clavina fumegante (ALENCAR, 1952, p. 137).

Figura 12 - Trecho de // Guarany

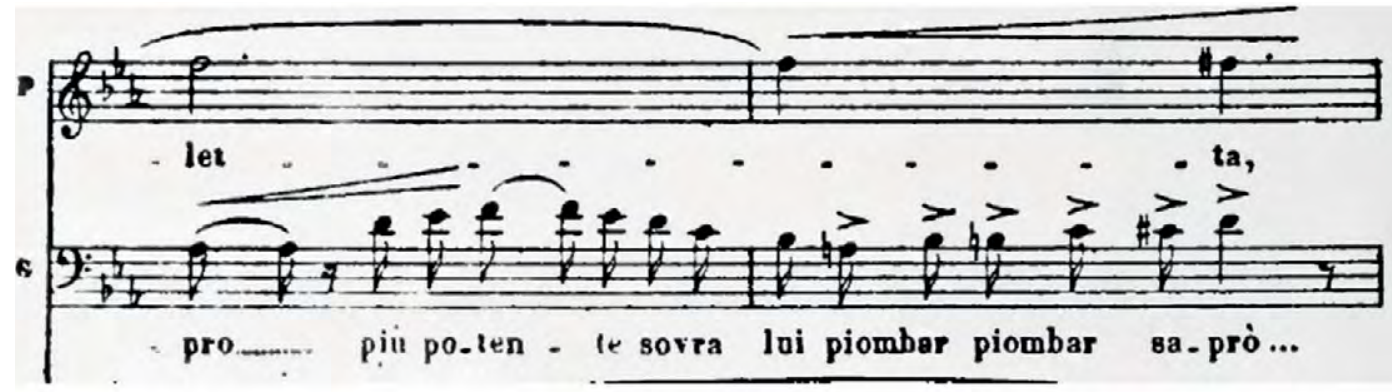

Fonte: Carlos Gomes (1889, p. 134).

A última cena deste ato se desenvolve no quarto de Cecília, à noite, quando, no romance de Alencar, "De repente cortou o silêncio da noite voz argentina, que cantava uma antiga xácara portuguesa, com sentimento e expressão arrebatadora. Os sons doces de uma guitarra espanhola faziam o acompanhamento da música" (1952, p. 199). Carlos Gomes mantém os sons de guitarra. C'era una volta un príncipe é repleto de vocalizes agudos e, neste sentido,

As agudas tessituras, implicando em vozes tendenciosamente claras, associam esse timbre com a noção de pureza e juventude. Elas refletem o tipo da ingênua amorosa (RATZERSDORF, 2002, p. 29).

A Cecília literária encontra na xácara portuguesa todo "sentimento e expressão arrebatadora” (ALENCAR, 1952, p. 199), próprios para a mocinha romântica que está prestes a se apaixonar.
$\mathrm{Na}$ balada, nota-se sentimento e expressividade por meio de técnicas especificas, que são aplicadas ao canto desta personagem. Podem-se, portanto, observar a agilidade no legato (Figura 13) e a passagem de um canto quase falado para o trinado (Figura 14), além de a sustentação e a equalização de som se manterem durante as transições de frases musicais, especificidades que também podem ser sentidas dentro da técnica do bel canto (Figura 15). É o momento da ópera que confirma o romantismo do perfil psicológico de Ceci, casta, angelical e pronta para se apaixonar, além da "exteriorização do discurso melodramático" (RUBERTI, 1972, p. 83). 
Figura 13 - Trecho de // Guarany

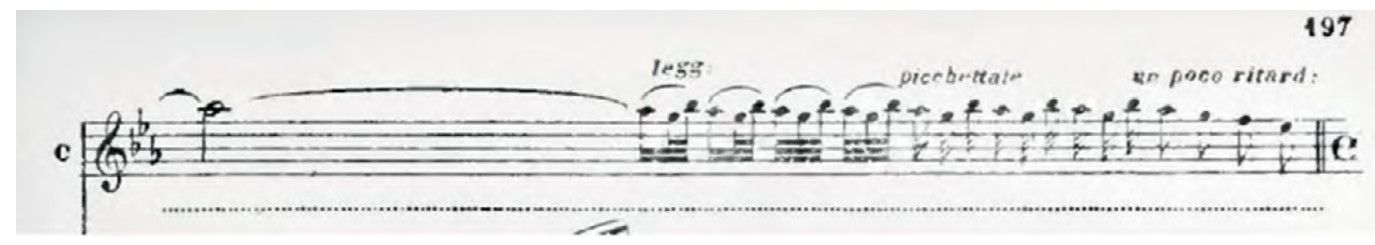

Fonte: Carlos Gomes (1889, p. 197).

Figura 14 - Trecho de I/ Guarany

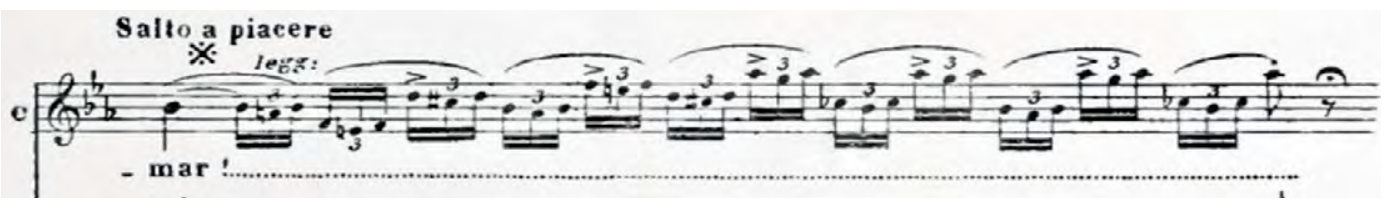

Fonte: Carlos Gomes (1889, p. 197).

Figura 15 - Trecho de // Guarany

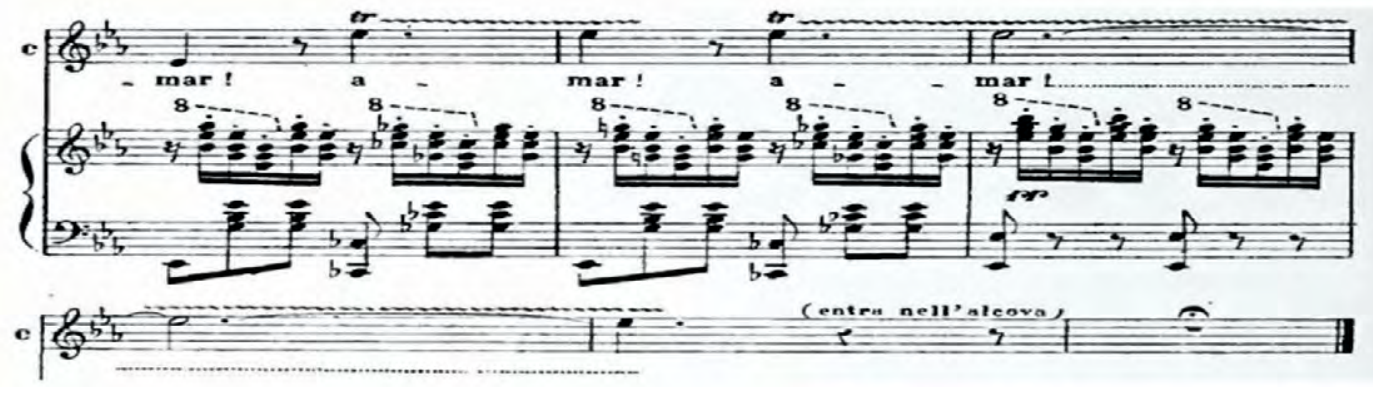

Fonte: Carlos Gomes (1889, p. 200).

Enquanto o segundo ato termina com a representação da batalha entre brancos e indígenas, o terceiro inicia com Cecília, feita prisioneira. Neste momento, também aparece a figura do cacique, acompanhado pelo coro dos aimorés. Carlos Gomes mantém o caráter indianista, marcado por uma forte instrumentalização da figura indígena. As alusões ao canto e à dança são os elementos escolhidos como meios de expressão das práticas tribais por Alencar, sendo a última descrita como evento bárbaro e demoníaco:
À medida que se animavam, a cadência apressava-se de modo que a marcha triunfal dos guerreiros se tornava uma dança macabra, uma corrida veloz, uma valsa fantástica, em que todos esses vultos horrendos, cobertos de penas que brilhavam à luz do sol, passavam como espíritos satânicos, envoltos na chama eterna (ALENCAR, 1952, p. 303).

$\mathrm{Na}$ ópera gomesiana, as cenas coreográficas repercutem características voltadas tanto para ilustrações despretensiosas, sugerindo a cor local, como escreve Virmont, "O balé, elemento essencial da grand ópera, se faz presente 
na ópera do período de transição. Muitas vezes desprovido de interesse para a continuidade da ação dramática, o balé apresenta o apelo ao grandioso e ao colorido local" (2012, p. 200), quanto para o não civilizado, como destaca Mammì:

O bailado do Guarany está longe de ser uma obra-prima, muito pelo contrário: é possivelmente a seção da partitura que mais envelheceu. No entanto, está aqui, pela primeira vez, aquela sonoridade caudalosa e quase amorfa, propositadamente exagerada para representar a pujança pré-histórica da natureza - uma música, enfim, que flerta com o ruído para ser absolutamente selvagem, pré-cultural e pré-linguística (2001, p. 50).
Além das danças, os coros aimorés de Il Guarany funcionam como demonstrações da cultura autóctone, não civilizada, que se destaca por meio da densidade das vozes, soando de maneira fortíssima (Figura 16). O prolongamento de notas no vocal em sílabas dá a ideia de tensão, suspense e força (Figura 17). Trata-se de um conjunto sonoro perfeitamente ajustado, no qual predominam acordes dissonantes, voltados a produzir um efeito de estranhamento que recorde o selvagem.

Figura 16 - Trecho de I/ Guarany

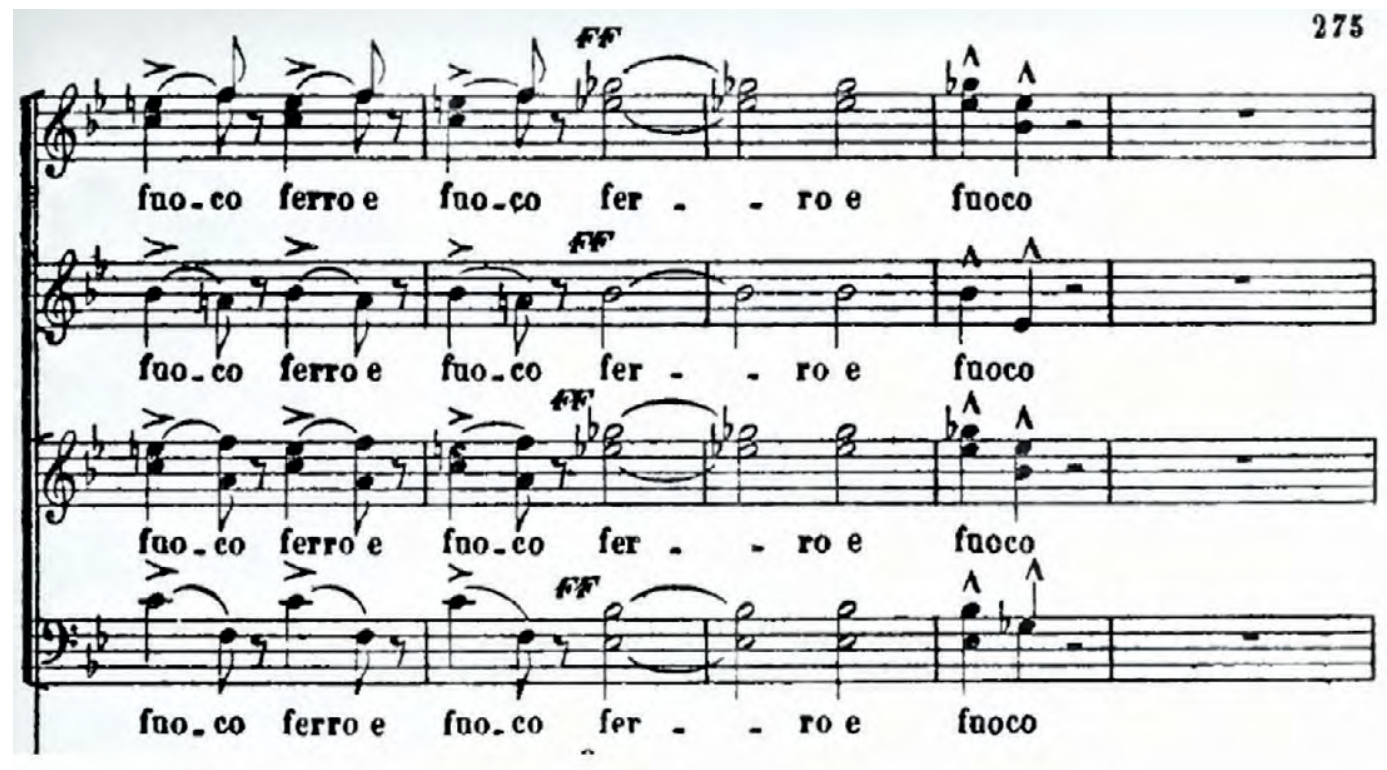

Fonte: Carlos Gomes (1889, p. 275). 
Figura 17 - Trecho de // Guarany

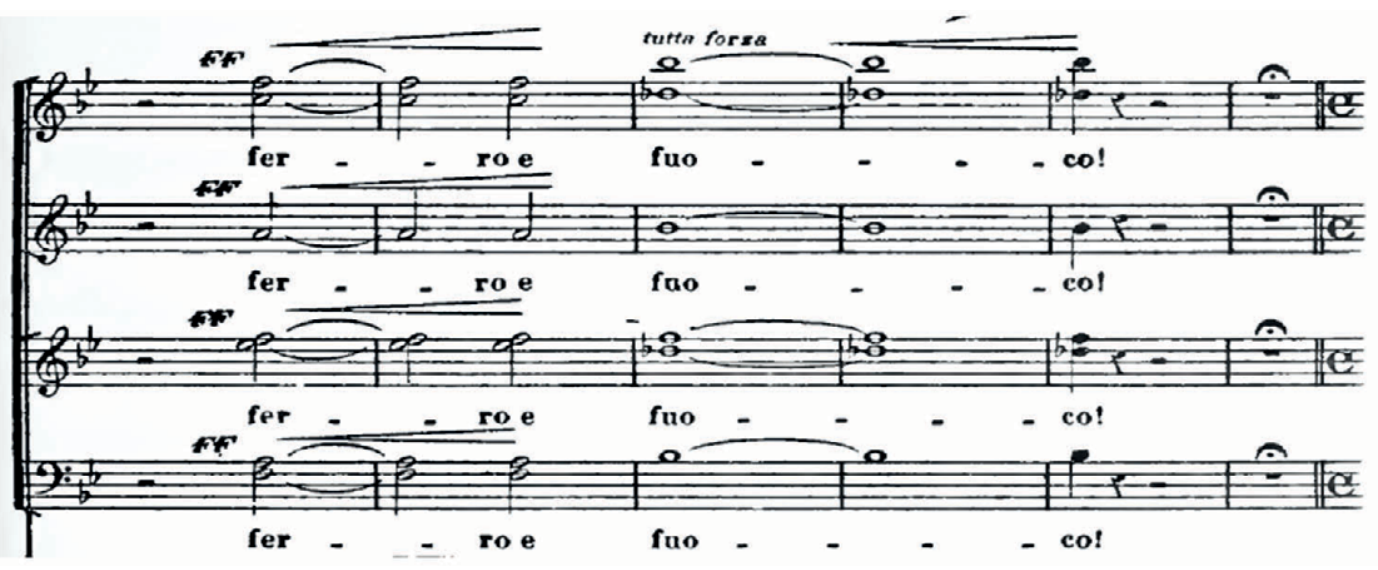

Fonte: Carlos Gomes (1889, p. 275).

Além disso, há uma predominância do coro de baixos, com solos específicos, se integrando ao contexto indígena, para acentuar o tom lúgubre da representação do rito aimoré (Figura 18), o que recria musicalmente a imagem literária de Alencar (1952), por intermédio de sons mais graves e guturais e do prolongamento de notas. Trata-se de uma alusão aos sons rústicos, "pré-culturais".

Figura 18 - Trecho de // Guarany

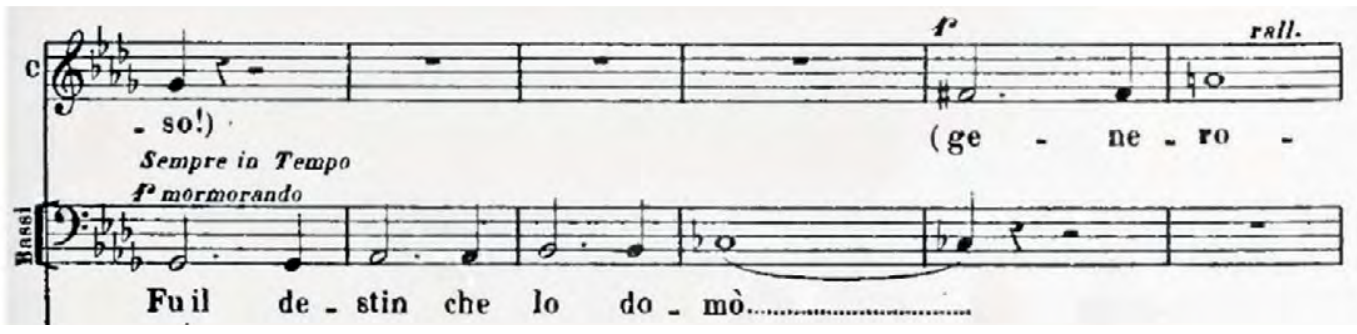

Fonte: Carlos Gomes (1889, p. 305).

Neste terceiro ato, na apresentação do cacique aimoré, Gomes confirma a plástica integração entre natureza e figura indígena, própria do romantismo indianista, do qual a descrição do cacique é um exemplo:
Os guerreiros se afastaram, as folhas se abriram, e entre aquelas franjas de verdura assomou o vulto gigantesco do velho cacique. Duas peles de tapir ligadas sobre os ombros cobriam seu corpo como uma túnica; um grande cocar de penas escarlates ondeava sobre sua cabeça e realçava-lhe a grande estatura (ALENCAR, 1952, p. 304). 
Gomes mantém a dimensão majestosa do quadro, seja pela força do coro, seja pela "vibração irada da orquestra, em extrema progressão sonora" (RUBERTI, 1972, p. 86). O compositor marca o canto de entrada do cacique com oitavas descendentes (Figuras 19 e 20), como observou Mammì (2001), dando ideia do poder, da autoridade que detém o líder dos aimorés.

Figura 19 - Trecho de // Guarany

CACICO

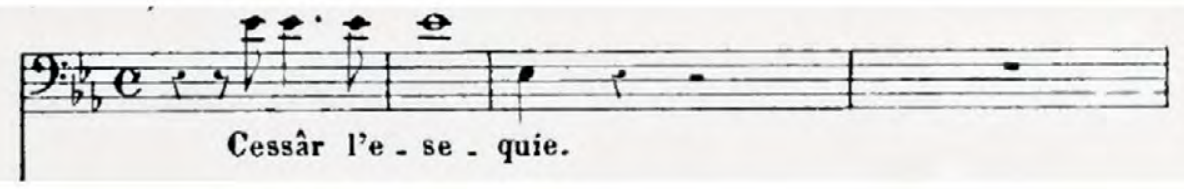

Fonte: Carlos Gomes (1889, p. 345).

Figura 20 - Trecho de // Guarany

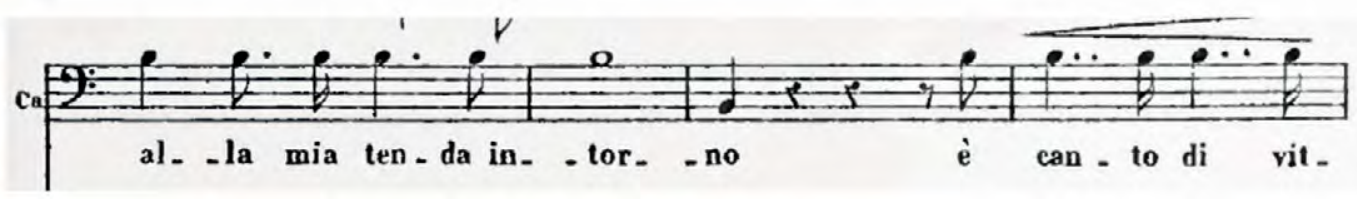

Fonte: Carlos Gomes (1889, p. 289).

A maneira encontrada por Gomes para musicalizar a personalidade do homem mais poderoso da tribo foi manter no personagem os sons "roucos e guturais que saíam dos lábios do selvagem" (ALENCAR, 1952, p. 304). Na escritura musical para voz, percebe-se quanto o alcance da extensão escolhida para representar o grande cacique aproxima-se da construção literária de Alencar. As notas graves, que chegam neste trecho ao Lá $1^{6}$ (Figura 21), transmitem a sonoridade escura do personagem.

Figura 21 - Trecho de // Guarany

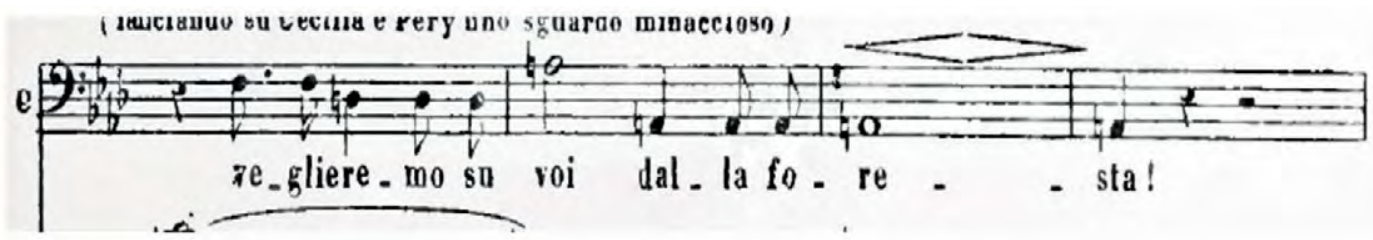

Fonte: Carlos Gomes (1889, p. 347). 
Depois de todo o jogo cênico entre o cacique e Ceci, em que o líder indígena admira a beleza da jovem branca, por "meios expressivos que acompanham a ação decisivamente, de modo especial com crescentes improvisos e acordes secos dos metais" (RUBERTI, 1972, p. 86), Peri entra em cena. Nesse momento, a construção vocal representa a condição de herói do personagem, pois seu diálogo é composto por notas agudas e ligaduras que se estendem por mais de um compasso (Figura 22).

Seu autodomínio e segurança são visíveis, pois se deixou fazer prisioneiro para resgatar Ceci, permanecendo impassível e sereno.

Figura 22 - Trecho de I/ Guarany

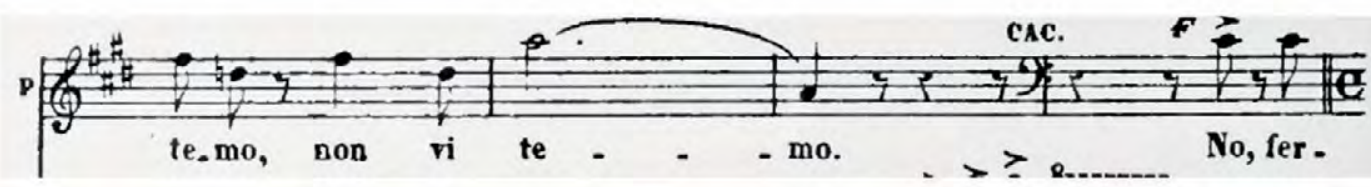

Fonte: Carlos Gomes (1889, p. 308).

No romance, a prisão de Peri e seu confronto com o cacique são dramatizados por meio de expressões musicais, o que se evidencia no momento em que $o$ jovem indígena se vê dominado pelos aimorés: "O coro dos selvagens respondeu a esta espécie de canto guerreiro, que preludiava o grande sacrifício" (ALENCAR, 1952, p. 306). Essa alusão ao contexto musical é estratégia textual para caracterizar os aimorés como povo de conduta incivilizada e selvagem, confirmada pela descrição da emissão de sons guturais, graves e escuros, próprios das forças da natureza em sua plena liberdade: "Os instrumentos retumbaram de novo; os gritos e os cantos se confundiram com aqueles sons roucos e reboaram pela floresta como o trovão rolando pelas nuvens" (ALENCAR, 1952, p. 307).

$\mathrm{Na}$ ópera, o coro dos indígenas utiliza emissões graves com frases em staccato, dando intensidade à invocação do sagrado (Figura 23), representado em $O$ Dio degli Aimorè. 
Figura 23 - Trecho de /l Guarany

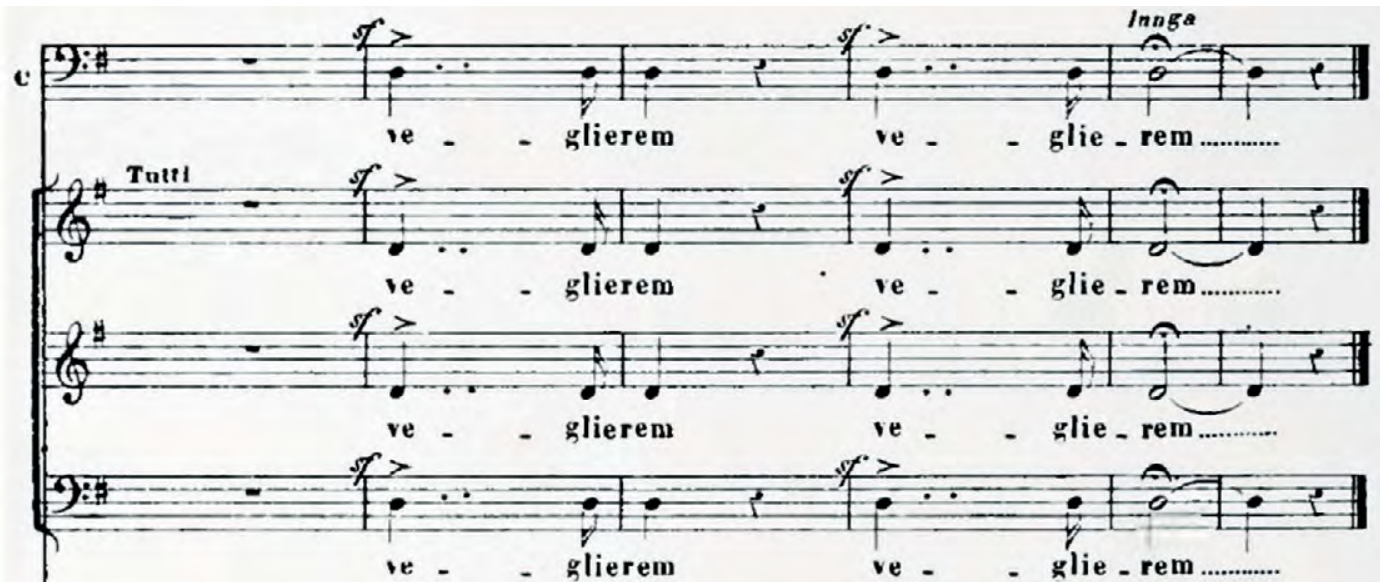

Fonte: Carlos Gomes (1889, p. 378).

No fim do terceiro ato, coloca-se o dueto entre Ceci e Peri, Perchè di meste lagrime, no qual o processo de amadurecimento dos personagens, agora conscientes do amor que sentem um pelo outro, é expresso pelas diferentes características vocais de Ceci, que abandona variações de coloratura para adotar uma melodia mais estável, com notas mais prolongadas. Se no início da ópera a composição de Gomes dava conta de mostrar a Ceci ingênua e sonhadora por meio da leveza da coloratura, neste momento, esta técnica será utilizada com propósitos dramáticos, ao estilo verdiano. Note-se que a utilização da coloratura, tanto em momentos de leveza quanto em mais graves, ficou muito conhecida a partir das composições de Giuseppe Verdi. Tal influxo é perceptível nas diferentes coloraturas de Ceci, para conferir-lhe a leveza do início e a maturidade nas melodias finais, dando-lhe maior peso e amplitude, como assinala Ratzersdorf (2002).

No caso específico de Perchè di meste lagrime, a composição vocal de Ceci se faz por meio de dinâmicas de alternância e de tempo, com mudanças de mínimas e semínimas para colcheias (Figura 24) e no prolongamento de notas mais agudas, utilizando mínimas, figuras de maior tempo (Figura 25):

Figura 24 - Trecho de // Guarany

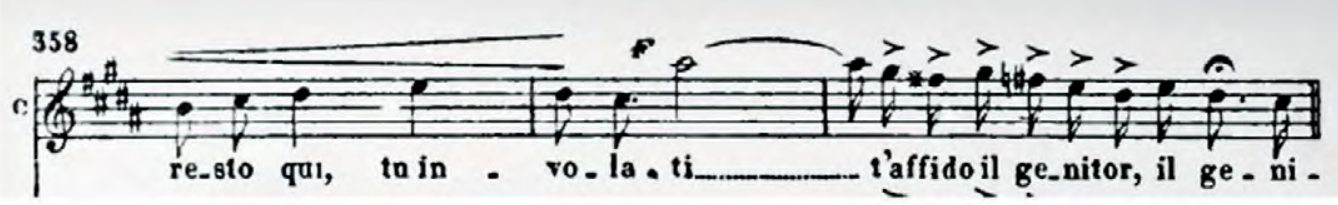

Fonte: Carlos Gomes (1889, p. 358). 
Figura 25 - Trecho de // Guarany

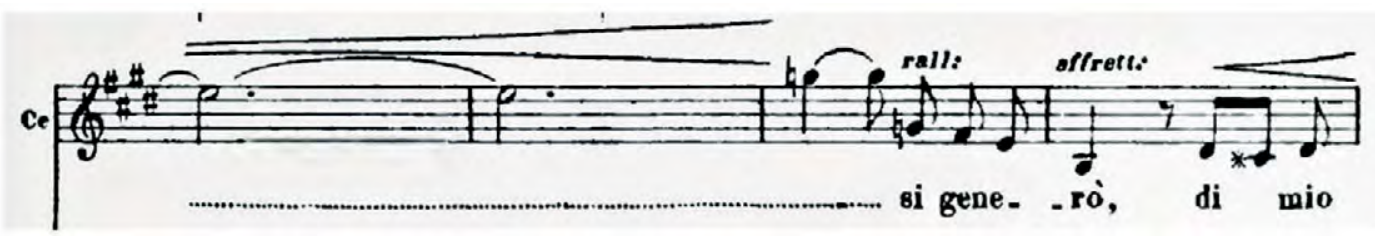

Fonte: Carlos Gomes (1889, p. 357).

Em Perchè di meste lagrime, a força de Peri, já cantada em outros momentos, é confirmada por meio das ligaduras, que aumentam a correspondência entre as notas, completando as frases e, conse- quentemente, trazendo maior expressividade a situação cantada (Figuras 26). Além disso, sua voz é levada a momentos de crescente força, confirmando sua dimensão heroica (Figura 27).

Figura 26 - Trecho de // Guarany

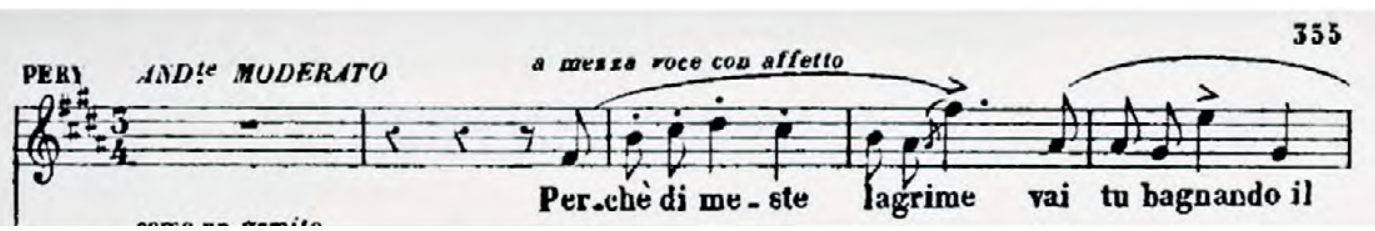

Fonte: Carlos Gomes (1889, p. 355).

Figura 27 - Trecho de // Guarany

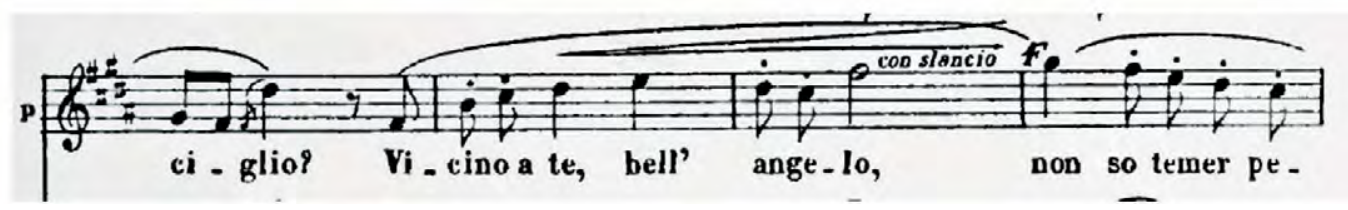

Fonte: Carlos Gomes (1889, p. 355).

Se no primeiro dueto o encontro final das vozes de Peri e Ceci denota a reciprocidade da paixão nascente, neste, em que os personagens já estão completamente envolvidos, as vozes têm ornamentos e construções melódicas distintas para novamente se encontrarem em expressões, notas e ritmos iguais ao final (Figura 28), dando ideia de estarem completamente ligados, unidos. 
Figura 28 - Trecho de // Guarany

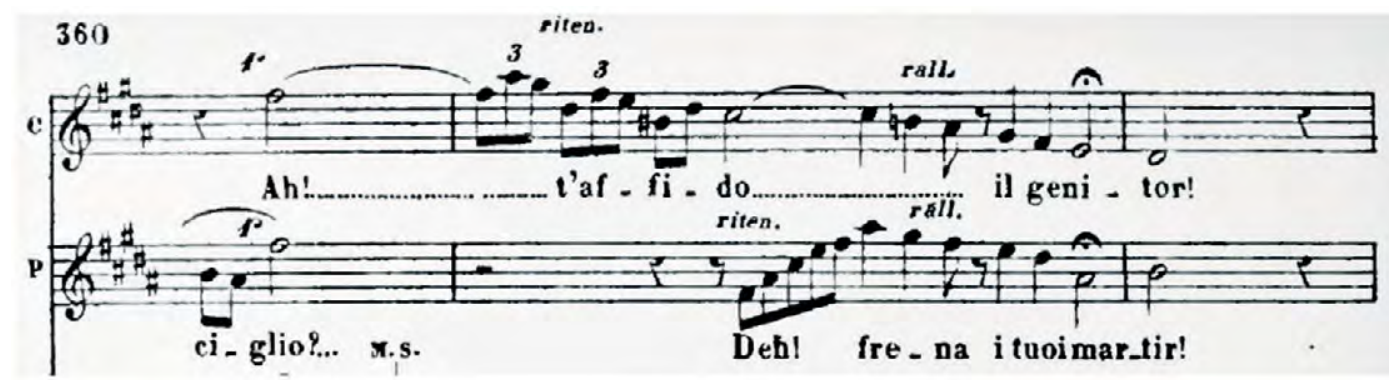

Fonte: Carlos Gomes (1889, p. 360).

Em uma das últimas cenas deste ato, os índios retornam e são surpreendidos por Dom Antônio e por um grupo de portugueses que, juntos, lutam contra os aimorés. Ceci vai ao encontro de seu pai, e Peri sai de cena. O momento do embate é bem representado musicalmente por meio de um $t u t t i^{7}$ orquestral. Com a progressão das cordas, tanto de maneira ascendente quanto descendente, $o$ ritmo sincopado dos metais instaura uma atmosfera de guerra.

No quarto e último ato, no momento de maior ênfase - antes da grande explosão em que os únicos a salvarem-se são Ceci e Peri -, acontece a Scena del Battesimo. No dueto Sul cupo torrente, Peri reaparece, e Dom Antônio lamenta a própria condição: seus domínios estão cercados pelos aimorés e por Gonzales, que, liderando os demais aventureiros, se prepara para entregá-lo, assim como tudo o que é dele, aos indígenas. Peri se oferece para salvar Ceci, e o fidalgo aceita, com a condição de que o índio se converta ao cristianismo. De fato, na narrativa de Alencar, o indígena só é admissível como herói e par amoroso de Ceci sob pacto de negação da própria identidade cultural:

Peri tinha abandonado tudo por ela; seu passado, seu presente, seu futuro, sua ambição, sua vida, sua religião mesmo; tudo era ela, e unicamente ela; não havia pois que hesitar (ALENCAR, 1952, p. 377).

O batismo de Peri funciona, assim, como forma de representação do domínio português sobre o indígena, marcando a relação do colonizador e do colonizado, com o predomínio cultural do primeiro:

O índio caiu aos pés do velho cavalheiro, que impôs-lhe as mãos sobre a cabeça.

- Se cristão! Dou-te o meu nome.

Peri beijou a cruz da espada que o fidalgo lhe apresentou, e ergueu-se altivo e sobranceiro, pronto a afrontar todos os perigos para salvar sua senhora (ALENCAR, 1952, p. 352).

$\mathrm{Na}$ ópera, a cena é representada pelo dueto entre o baixo, o fidalgo português, e o tenor, o herói indígena. A aproximação entre ambos é marcada pela equiparação das vozes, porém sem a junção em uníssono: não há a confluência melódica e rítmica para cantarem exatamente as mesmas notas, nas mesmas extensões. Isso indica que, apesar da convergência, cada um possui uma origem evidente- 
mente distinta, no entanto é perceptível a junção das diferenças rumo à comunhão cristã, um dueto do não civilizado com o civilizado.
O instante em que o selvagem professa a fé cristã assinala o ponto de encontro entre as melodias (Figura 29).

Figura 29 - Trecho de // Guarany

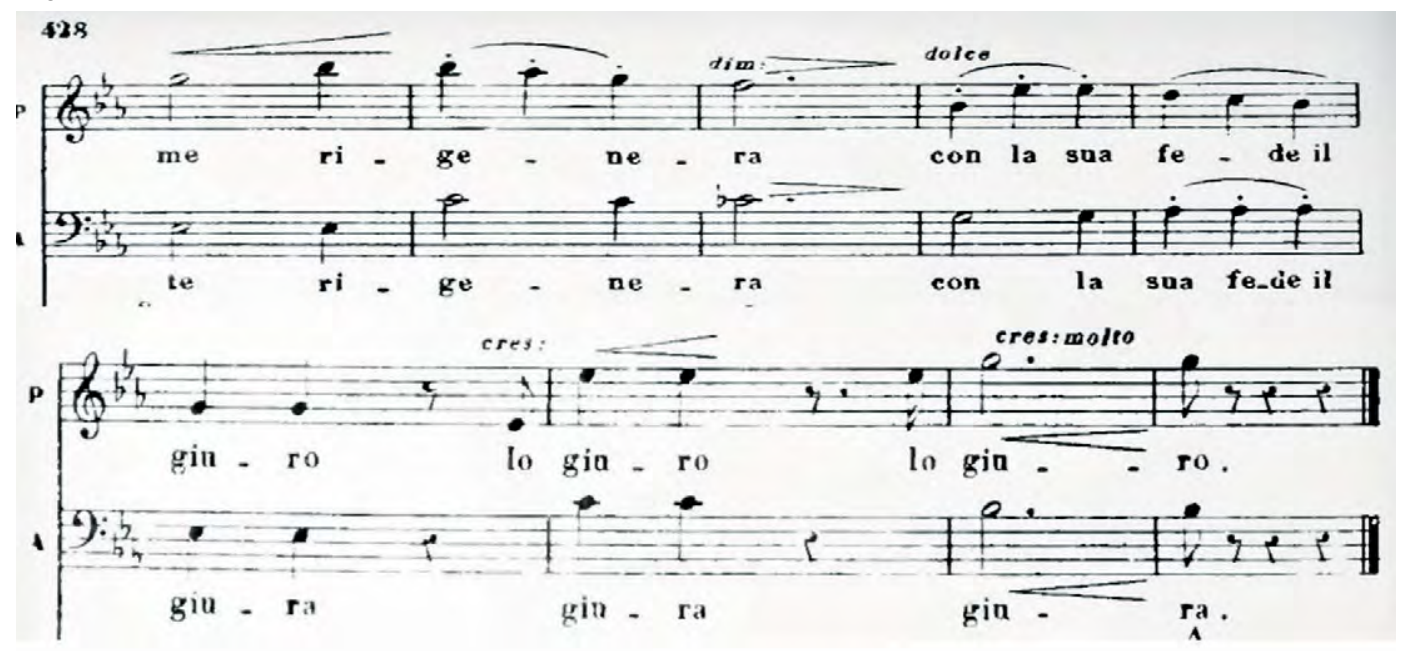

Fonte: Carlos Gomes (1889, p. 428).

\section{Considerações finais}

As afinidades entre Carlos Gomes e José de Alencar são mais profundas do que as arroladas até aqui e revestem-se de complexidades que vão além das inerentes ao processo de transcrição de uma obra literária para outra forma de expressão artística. Para entendê-las, se faz necessário levar em consideração as peculiaridades do romantismo brasileiro e as de caráter sociocultural do período, bem como o papel exercido por ambos os autores dentro do esforço para criação e consolidação de instituições em todos os campos de atividade, em especial, no da estética. Nesse sentido, Alencar não deixou nada a desejar, pois sozinho fez mais do que os demais prosadores de sua época, produzindo romances sobre os mais variados temas, propondo ambientações inovadoras, criando personagens que permanecem vivos e, sobretudo, encontrando uma linguagem para a nossa literatura.

Carlos Gomes fez algo análogo em relação à música operística, e o fato de ter produzido sua obra a partir de outra, além de não o desmerecer, evidencia um dos pontos que sua trajetória tem em comum com a do romancista, porque Alencar escreveu $O$ Guarani como resposta 
aos ataques que sofreu pelas críticas a $A$ confederação dos Tamoios, de Gonçalves de Magalhães. Neste aspecto, o compositor comprovou o acerto do escritor que, dando lume ao romance, mostrou pela linguagem e pelos procedimentos qual gênero era mais adequado para tratar do tema, pois procurou se manter o mais próximo possível do modelo que o inspirou. Resguardadas as singularidades das respectivas trajetórias e das condições que as impulsionaram, observa-se que foram dois indivíduos cujo espírito criador se animava pela mesma ambição: modernizar as artes brasileiras.

Em contrapartida, a proposta que embasa a composição de Carlos Gomes não está inteiramente relacionada ao contexto nacionalista que alicerçou a escrita alencariana. $\mathrm{O}$ compositor pertence a um romantismo tardio, em que as primeiras necessidades de construção dos aspectos nacionais brasileiros já não estavam em destaque, no entanto havia a necessidade de confirmar um perfil próprio para os diversos campos artísticos do Brasil, ao mesmo tempo em que, do ponto de vista político-administrativo, as demandas eram outras. Embora utilize a língua italiana ou tenha sido receptor das obras e do estilo de nomes como Verdi ou Meyerbeer, criando a partir desta recepção suas próprias composições, Carlos Gomes buscou expressar traços particulares à cultura brasileira. O compositor cria em Il Guarany concepções musicais distintas, porém o arranjo musical mantém vivo o diálogo com o homônimo literário. A importância da música vocal na ópera de Carlos Gomes está relacionada ao contexto do romantismo da segunda metade do século XIX, em que há uma busca não apenas para musicalizar textos, mas também, como pondera Virmond (2012), para descrever reações psicológicas coerentes com seu conteúdo dramático. O tratamento vocal, portanto, cuida de aproximar o discurso dramático do musical, o que se ajusta à ideia de expressividade mais intensa e vigorosa que é sentida na ópera Il Guarany.

\section{The voices of indianism in Il Guarany}

\begin{abstract}
The romanticism in Brazil must be seen as an inseparable movement from the effort to create a country and its institutions that, in all forms of cultural expression, has transformed the indigenous into a symbol of the nation. From this perspective, this article analyzes the creative reception that Carlos Gomes gave to the novel O Guarani (1952) by José de Alencar, first published in 1857, through the opera Il Guarany (1870). In order to do so, the analysis focuses on the importance of vocal composition for the re-creation of the characters psychological characteristics, which allows us to note the composer's commitment to avoid as little as possible the traits defined by the novelist and therefore guarantee the preservation of connections between Literature and opera, while respecting the peculiarities of the respective languages.
\end{abstract}

Keywords: Brazilian literature. History of literature. Literature and music. 


\section{Notas}

Refere-se ao conjunto de todas as notas que um cantor consegue articular (GURRY, 2014).

2 É o que caracteriza a voz, a identidade vocal. $\mathrm{E}$ por possuir qualidades específicas é comum atribuir adjetivos ao seu som, como brilhante, claro, escuro, denso, leve, entre outros. Alguns professores de canto também utilizam termos como "ter ponta" no som ou "ter corpo" vocal, que ilustram metaforicamente os extremos desejáveis no acabamento técnico de uma voz (GURRY, 2014).

3 O termo coloratura refere-se à transformação de notas longas/brancas em componentes pretas, trazendo um efeito elaborado à ornamentação da melodia (RATZERSDORF, 2002).

4 O bel canto desenvolveu-se por intermédio do estudo constante e do controle de aspectos físicos, a partir da emissão do som, utilizando técnicas específicas de respiração, flexibilidade, passagem de registros com segurança e controle em notas longas. Tudo isso associado à beleza do timbre e ao volume da emissão vocal permite que o cantor demonstre com sua voz todas as emoções que o compositor deseja transmitir.

5 Notas executadas com qualidade dentro da extensão vocal do cantor (GURRY, 2014).

6 Diz respeito às oitavas musicais dentro da extensão de cada classificação vocal, por exemplo, o baixo geralmente consegue cantar do Sol 1 até o Sol 3, normalmente duas oitavas. Sendo assim, Lá 1 está dentro da região mais grave que o baixo pode atingir.

7 Neste contexto musical, diz respeito ao momento em que todos os instrumentos tocam juntos.

\section{Referências}

ALENCAR, José de. O Guarani. São Paulo: Gráfica Editora Brasileira, 1952.

GOMES, Carlos. Il Guarany. Milão: Ricordi, 1889. Disponível em: <http://imslp.org/wiki/ Il_Guarany_(Gomes,_Carlos)>. Acesso em: 21 jul. 2015.

GURRY, Néstor Ramón Cordeiros. A Voz de Tenor: bases históricas da pedagogia vocal a partir do Bel Canto até os conceitos metodológicos da atualidade. 2014. Dissertação
(Mestrado em Música) - Universidade Federal de Minas Gerais, Belo Horizonte, 2014.

ISER, Wolfgang. L'atto della lettura: una teoria della risposta estetica. Bolonha: El Murino, 1987.

JAUSS, Hans-Robert. Estetica della Ricezione. Nápoles: Guida, 1988.

Perché la storia della letteratura? Tradução do alemão para o italiano de Alberto Vàrvaro. Nápoles: Guida, 1969.

MAMMÌ, Lorenzo. Carlos Gomes. São Paulo: Publifolha, 2001.

RATZERSDORF, Maria Elisabeth. O soprano ligeiro na ópera: sua arte e otimização de sua técnica. Dissertação (Mestrado em Artes) - Universidade Estadual de Campinas, Campinas, 2002. Disponível em: <http://www. bv.fapesp.br/pt/bolsas/102306/o-soprano-ligeiro-na-opera-sua-tecnica-delimitando-suas-personagens/>. Acesso em: 19 abr. 2017.

RUBERTI, Salvatore. O Guarani e Colombo de Carlos Gomes. Rio de Janeiro: Laudes, 1972.

TANK, Niza de Castro. Minhas Pobres Canções - Antônio Carlos Gomes. São Paulo: Algol, 2006.

VIRMOND, Marcos. Carlos Gomes no contexto da transição da ópera italiana. In: VOLPE, Maria Alice (Org). Atualidade da Ópera. Rio de Janeiro: UFRJ, Escola de Música, 2012. p. $195-222$. 